\title{
Association of nutritional status and anemia with multi- micronutrient supplementation in young children in Peru
}

\section{Asociación del estado nutricional y anemia según suplementación con múltiples micronutrientes en niños pequeños en Perú}

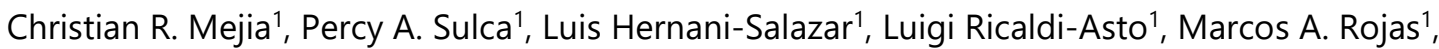 \\ Gustavo Hernández-Arriaga ${ }^{2}$, Marcos Roberto Tovani-Palone ${ }^{3}$, Lotty Bueso-Pineda ${ }^{4}$
}

\begin{abstract}
Introduction: Although several social interventions have been developed by the Peruvian State, anemia is present in one out of every two children in Peru. Thus, it is important to evaluate whether such interventions are achieving their objectives.

Objective: This study aimed to determine the association of nutritional status and anemia with multi-micronutrient supplementation in children younger than three years in Huancayo, Peru.

Materials and Methods: This retrospective, longitudinal, analytical, and observational study included secondary data of children younger than 3 years from the Sicaya District, in the Huancayo province. Data were collected from health center medical records. Nutritional and anemia status, and sociodemographic characteristics of children receiving multi-micronutrient supplementation were recorded. Statistical analyses were based on generalized linear models.

Results: Data of 76 children with available medical records were analyzed, and their pre- and post-intervention median ages were 6 and 11 months (range: 7-35 months), respectively. Significant positive linear correlations were observed between the number of multi-micronutrient doses and weight, height, and hemoglobin concentration. In bivariate and multivariate analyses, no significant associations were observed between anthropometric measurements and anemia (after multi-micronutrient intervention) $(p>0.05)$, nor between the number of received doses of multi-micronutrients, sex and age.

Conclusion: Multi-micronutrient supplementation may be correlated with both physiological and anthropometric variables, but not with indicators of child development. These associations require further evaluations to determine whether social programs promoting multi-micronutrient supplementation improve the development of children with anemia.
\end{abstract}

Keywords: micronutrients, dietary supplements, nutritional status, anemia, children

\section{RESUMEN}

Introducción: Aunque muchas intervenciones sociales han sido desarrolladas por el Estado peruano, la anemia está presente en uno de cada dos niños en Perú. Por lo tanto, es importante evaluar si tales intervenciones están logrando sus objetivos.

Objetivo: Este estudio tuvo como objetivo determinar la asociación del estado nutricional y la anemia con la suplementación con múltiples micronutrientes en niños menores de tres años en Huancayo, Perú.

Materiales y Métodos: Este estudio retrospectivo, longitudinal, analítico y observacional, incluyó datos secundarios de niños menores de 3 años del distrito de Sicaya, en la provincia de Huancayo. Los datos se obtuvieron de los registros médicos del centro de salud. Se registraron el estado nutricional y de anemia, y las características sociodemográficas de los niños que reciben suplementos de micronutrientes múltiples. Los análisis estadísticos se basaron en modelos lineales generalizados.

Resultados: Se analizaron los datos de 76 niños con registros médicos disponibles, y sus edades medias antes y después de la intervención fueron 6 y 11 meses (rango: 7-35 meses), respectivamente. Se observaron correlaciones lineales positivas significativas entre el número de dosis de multimicronutrientes y el peso, la altura y la concentración de hemoglobina. En los análisis bivariados y multivariados, no se observaron asociaciones significativas entre las mediciones antropométricas y la anemia (después de la intervención con multi-micronutrientes) $(p>0,05)$, ni entre el número de dosis de multi-micronutrientes recibidos, sexo y edad.

\footnotetext{
1 Universidad Continental, Huancayo, Peru.

2 Facultad de Medicina y Cirugía, Universidad Católica de Honduras, San Pedro Sula, Honduras.

3 Ribeirão Preto Medical School, University of São Paulo, Ribeirão Preto, Brazil.

4 School of Nursing, Trinity Western University, Langley, BC, Canada.
}

Correspondence: Christian R. Mejia

Escuela de Medicina Humana, Universidad Continental, Huancayo, Perú.

E-mail: christian.mejia.md@gmail.com

Received: 2 Aug 2019, Accepted: 11 Oct 2019

(C) 2019 by the authors; licensee Modestum Ltd., UK. This article is an open access article distributed under the terms and conditions of the Creative Commons Attribution License (http://creativecommons.org/licenses/by/4.0/).

Electronic Journal of General Medicine 
Conclusión: La suplementación con micronutrientes múltiples puede correlacionarse tanto con variables fisiológicas como antropométricas, pero no con indicadores de desarrollo infantil. Estas asociaciones requieren evaluaciones adicionales para determinar si los programas sociales que promueven la suplementación con micronutrientes múltiples mejoran el desarrollo de los niños con anemia.

Palabras clave: micronutrientes, suplementos dietéticos, estado nutricional, anemia, niños

\section{INTRODUCTION}

Multi-micronutrients (MMN) play vital roles in growth and development during childhood (1). Therefore, an adequate intake of these compounds may be essential during this period of life (2). MMN deficiency can lead to important adverse functional consequences, including poor cognitive development, inadequate growth, and reduced physical abilities. Some studies report that such deficiency may also reduce the intelligence quotient of children (3). Therefore, this is a serious problem, as indicated by cases of high prevalence of anemia, which suggest significant nutritional deficits (4). Moreover, this situation is often accompanied by deficiencies in other nutrients, including vitamin B12 and folic acid (5).

On the other hand, an adequate MMN supplementation has been reported to significantly reduce vitamin $A$ deficiency, anemia, and chronic malnutrition (6). In addition, an effective administration of MMN enhances responses to supplementation (7).

According to the Ministry of Health of Peru (MINSA), the prevalence of chronic malnutrition and of anemia among children younger than 3 years decreased by $7.3 \%$, and $19.3 \%$, respectively, during 2000-2001. In this context, poverty and a lack of prenatal monitoring have been correlated with the prevalence of anemia (8).

The findings of a study conducted in three Peruvian regions (Ayacucho, Huancavelica, and Andahuaylas) between 2009 and 2012 demonstrated that lipid based nutritional supplementation represents an effective anti-anemia strategy $(9,10)$. The National Plan for the Reduction and Control of Anemia, implemented by the MINSA in 2017, gives an estimate that shows that $44 \%$ of children aged 6-36 months still suffer from anemia (11). The MINSA has invested millions of soles (Peruvian currency) in the fight against anemia, but some specific investigations have found that the results achieved have not been satisfactory (12).

Up till now, few studies have evaluated the outcomes of implementing nutritional supplementation for children in Peru. Thus, our study aimed to determine the association of nutritional status and anemia with MMN supplementation in children younger than three years in Huancayo, Peru.

\section{MATERIALS AND METHODS}

This retrospective, longitudinal, analytical, and observational study was conducted from January to May 2015 at the Sicaya Health Center in Huancayo, Peru.

The study included children younger than three years who had received MMN supplementation since they were 6 months of age and were attended in a Growth and Development (Crecimiento y Desarrollo - CRED) office from a health facility in the Sicaya District, in the Huancayo province. Specifically, included children lived in the Sicaya District and had completed CRED control. Four records were excluded because of incomplete data. Census-type convenience sampling was applied.

Collected variables included sex, age, weight, height, last CRED control, hemoglobin levels, and the number of received doses of MMN (including folic acid, iron, zinc, vitamin A, and vitamin C; the latter was administered at a 1-g daily dose from 6 to 18 months of age).

Anthropometric data were collected and checked against the anthropometric nutritional assessment table for children $<5$ years old, which was developed by the World Health Organization and is generally used by the MINSA (13). Values within a standard deviation of \pm 2 were considered normal. The anthropometric analysis was based on the usual parameters for weight/age, height/age, and weight/height. To evaluate anemia, hemoglobin levels were determined in consideration of the regional altitude. Accordingly, the measured hemoglobin values were adjusted using an appropriate altitude-related factor. Hemoglobin cut-offs were: severe, moderate, and mild anemia that were defined using hemoglobin ranges of $<7.0,7.0-9.99$, and $10.0-10.99 \mathrm{~g} / \mathrm{dl}$, respectively.

Permission to conduct the study was requested from the relevant health facility, along with a document endorsed by the Dean of the Human Medical School of Continental University, Peru. The data were collected through an assistance/social program implemented by the Peruvian government in similar districts. Therefore, the studied population was very similar to those from other areas of moderate or extreme poverty. Furthermore, the dates and times 
Table 1: Pre- and post-supplementation with MMN versus physiological, demographic, and anthropometric variables in children from Huancayo, Peru

\begin{tabular}{|c|c|c|c|}
\hline \multirow{2}{*}{ Variable } & \multicolumn{2}{|c|}{ Intervention with MMN n (\%) } & \multirow{2}{*}{ p-value } \\
\hline & Pre & Post & \\
\hline Weight $(\mathrm{kg})^{\star}$ & $6.9(5.6-8.7)$ & $8.9(6.4-13.6)$ & $<0.001 \S$ \\
\hline Height $(\mathrm{m})^{\star}$ & $64.8(58-71)$ & $72.0(64-90)$ & $<0.001 \S$ \\
\hline Hemoglobin ${ }^{\star \star}$ & $10.9(1.0)$ & $11.1(0.6)$ & $0.075 £$ \\
\hline \multicolumn{4}{|l|}{ Weight/Age } \\
\hline Normal & $69(90.8)$ & $72(94.7)$ & $0.348 ¥$ \\
\hline Low weight-for-age & $4(5.3)$ & $7(9.2)$ & \\
\hline \multicolumn{4}{|l|}{ Height/Age } \\
\hline Normal & $66(86.8)$ & $68(89.5)$ & $0.616 \neq$ \\
\hline Low height-for-age & $10(13.2)$ & $8(10.5)$ & \\
\hline \multicolumn{4}{|l|}{ Weight/Height } \\
\hline Normal & $76(100.0)$ & $75(98.7)$ & $1.000 \mp$ \\
\hline Overweight-for-age & $0(0.0)$ & $1(1.3)$ & \\
\hline
\end{tabular}

$\mathrm{MMN}=$ multi-micronutrients. ${ }^{*}$ Median and range. ${ }^{* \star}$ Mean and standard deviation. P-value obtained with: $\S$ Mann-Whitney U test; $£$ paired Student's t-test; $¥$ Chi-square test; $\mp$ Fisher's exact test

of data collection were arranged with the head of the CRED service. A data collection sheet was developed to gather the relevant information and the double data entry was performed using a database Excel for Windows (Microsoft Corp., Redmond, WA, USA).

Data were statistically analyzed using STATA, version 11.1 (STATA Corp., College Station, TX, USA). Quantitative data were summarized using measures of central tendency and dispersion following a preliminary analysis of the normality of the variables. Qualitative data were summarized using frequencies and percentages. A statistical significance level of $p<0.05$ was set for statistical analysis. Categorical variables were analyzed using Chi-square or Fisher's exact test, while numerical variables were assessed using Student's $t$ or the Mann-Whitney $U$ test. Relative risk (RR), $95 \%$ confidence intervals $(\mathrm{Cl})$, and $\mathrm{p}$-values were obtained using generalized linear models together with a Poisson distribution and a log link function.

\section{Study Definition}

Multimicronutrients are vitamins provided by the Peruvian Government to children from low-income areas. Vitamins should be taken in small amounts in order to provide appropriate supplementation and positive impacts on the health, with an appropriate relation between weight/age, height/age, and weight/height.

\section{RESULTS}

Of the 76 children with records available at the health facility, $51.3 \%$ (39) were male. The pre- and post-intervention median ages were 6 (range: 6-6 months) and 11 months (range: 7-35 months), respectively. Table 1 presents the preand post-intervention physiological and anthropometric variables, and highlights the significant differences in weight and height over time, in contrast to other evaluated parameters (Table 1).

The number of MMN doses to the evaluated children was found to exhibit statistically significant positive linear correlations with hemoglobin concentration (Figure 1A, $p=0.032$ ), weight (Figure 1B, $p<0.001$ ), and height (Figure 1C, $\mathrm{p}<0.001$ ) (Figure 1).

Bivariate and multivariate analyses of the association between anthropometric values and anemia (post-MMN intervention) did not yield statistically significant findings. Similarly, no significant associations were observed for the number of MMN doses, sex, and age (Table 2). 

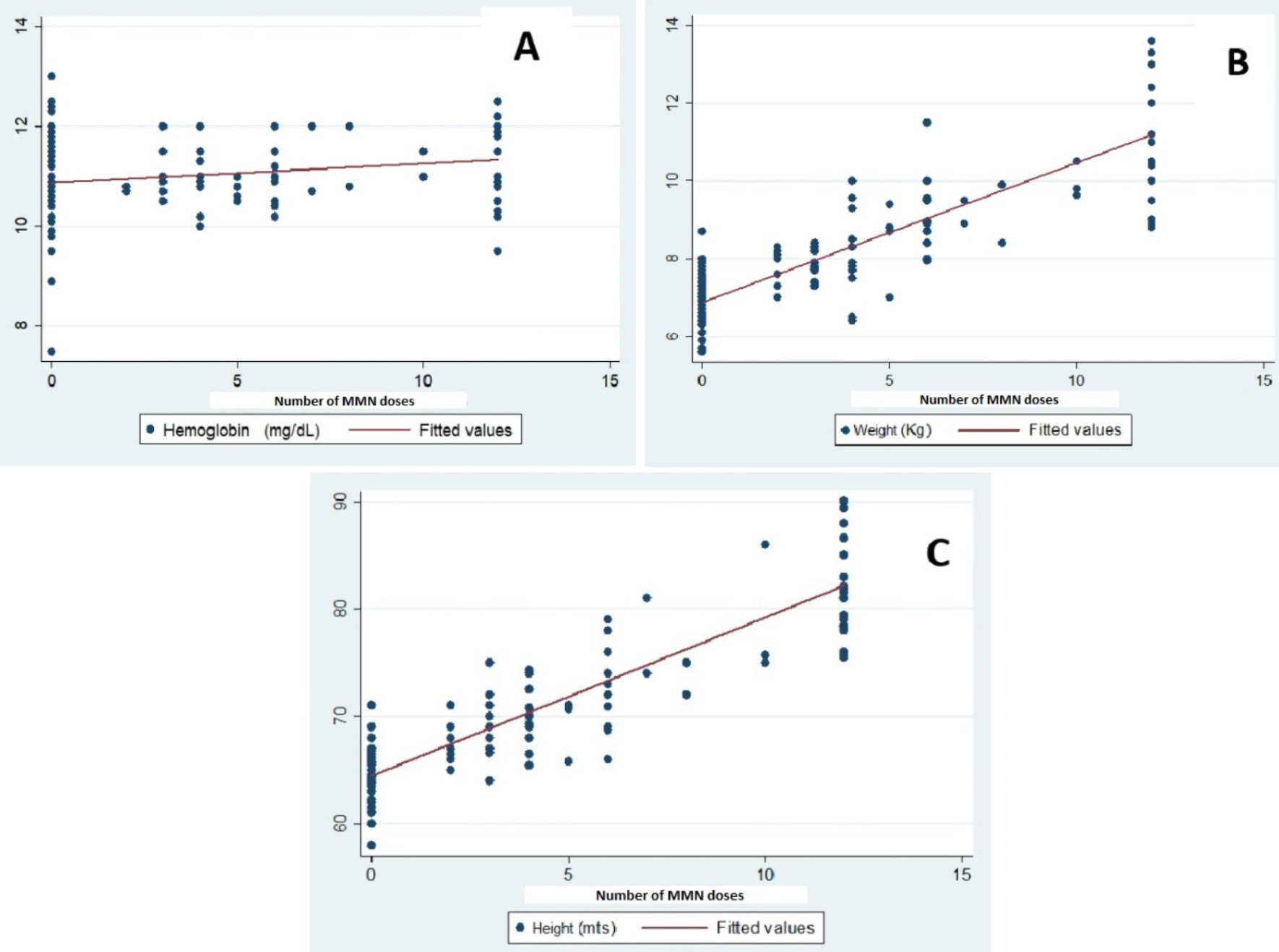

Figure 1: Correlation between the number of MMN doses and hemoglobin (A), weight (B), and height (C) of the studied children

$M M N=$ multi-micronutrients

Table 2: Analysis of the influence of MMN doses on temporal changes between demographic and anthropometric variables in children from the Sicaya District, in the Huancayo province

\begin{tabular}{|c|c|c|c|c|c|}
\hline \multirow{2}{*}{ Variable } & \multicolumn{2}{|c|}{ Post-intervention } & \multicolumn{3}{|c|}{ Adjusted by $\mathrm{RR}(95 \% \mathrm{Cl})$ and p-value } \\
\hline & With Anemia & Without Anemia & Bivariate & Doses & Doses+age+sex \\
\hline \multicolumn{6}{|l|}{ Weight/Age } \\
\hline Normal & $27(93.1)$ & $35(94.6)$ & $0.9(0.2-3.7)$ & $0.9(0.2-3.8)$ & $0.9(0.2-3.7)$ \\
\hline Low weight-for-age & $2(6.9)$ & $2(5.4)$ & 0.850 & 0.893 & 0.839 \\
\hline \multicolumn{6}{|l|}{ Height/Age } \\
\hline Normal & $25(86.2)$ & $34(91.9)$ & $0.7(0.3-2.1)$ & $0.6(0.2-1.9)$ & $0.6(0.2-1.9)$ \\
\hline Low height-for-age & $4(13.8)$ & $3(8.1)$ & 0.579 & 0.416 & 0.411 \\
\hline \multicolumn{6}{|l|}{ Weight/Height } \\
\hline Normal & $28(96.6)$ & $37(100.0)$ & $0.4(0.1-3.2)$ & $0.5(0.1-3.4)$ & $0.4(0.1-3.3)$ \\
\hline Overweight-for-height & $1(3.4)$ & $0(0.0)$ & 0.408 & 0.448 & 0.411 \\
\hline
\end{tabular}

$\mathrm{RR}=$ relative risk $\mathrm{Cl}=$ confidence intervals

\section{DISCUSSION}

In Peru, pediatric anemia is a public health problem $(10,13)$. It is known that such condition is associated with multiple factors, and one of the most important of them is the ingestion of nutrients, which should be obtained through an adequate diet (intake of milk, meat, and other foods in a well-balanced diet). However, there is often inability to meet basic food needs in low-income areas $(14,15)$. 
Anemia may affect a child's cognitive level (unless well controlled) when its onsets in early developmental stages. This nutritional disorder can thus lead to physical problems and to a poor quality of life (15). In Huancayo, the prevalence of anemia among children aged 6-35 months was 44.5\% in 2012, while the prevalence of chronic pediatric malnutrition was $24.6 \%$ (16). Consequently, MMN supplementation emerged as a strategy to reduce the prevalence of these indicators of poor health $(17,18)$. Despite this, no local study has been conducted to determine whether this intervention was beneficial; therefore, the findings of our study should be very important in this regard.

Although in this study some indicators improved in relation to MMN supplementation, the parameters of weight/age, height/age, and weight/height did not associate significantly with MMN intake. This differs from the findings of studies conducted in the Huando and Anchonga communities of Peru $(19,20)$, where MMN supplementation was found to affect the nutritional status of children younger than 3 years. This discrepancy may be attributable to a variety of causes, including lack coverage of actual intakes, a lack of parental knowledge about the importance and benefits of MMN supplementation, or non-compliance with other potentially influential factors.

In contrast, we observed statistically significant differences in weight, height, and hemoglobin values related to the number of MMN doses, which may be due to physiological development during childhood. In addition, the hemoglobin concentration increased by $0.2 \mathrm{~g} / \mathrm{dl}$ with the use of a daily regimen of supplementation for 12 months (30 sachets per month). Studies on the growth-MMN ratio have showed similar results, reporting an effect non-related to the use of a specific type of supplementation $(21,22)$.

Interestingly, in the present study, the increases in anthropometric values did not exhibit statistically significant associations with the number of received doses of $M M N$, the evaluated children's sex, or age. Nonetheless, the prevalence of anemia decreased slightly. Studies conducted in other locations within Latin America and elsewhere suggest that these improvements are insufficient because a significant reduction in anemia could not be achieved in the most affected populations, including children living in low-income rural areas $(23,24)$. This suggests, therefore, that supplementation is unsatisfactory, which may be attributable to the process of MMN preparation, inadequate intake, or other intervening factors (25); however, these issues are beyond the scope of our study. Further investigations are needed to determine at which point the social program failures occur, as this will allow corrective actions based on a more ambitious objective of reducing anemia in this population.

It is also worth noting that our findings are limited to the real setting in which children received care and MMN supplementation at the health center in Sicaya; therefore, the findings do not include pediatric populations from other towns or throughout Peru as a whole, and the conditions of those populations remain unknown. Additionally, as the study data were collected only from medical records, we were unable to gather other pertinent information regarding MMN intake. However, this study was conducted based on the use of MMN under similar conditions at several locations throughout Peru. Thus, our findings may serve as a good approximation of reality at provincial, departmental, and even national levels.

Limitations on weight and height values should also be taken into account, as these can be influenced by the normal growth pattern of patients. Data on weight and height were placed in Table 1 in order to characterize the population, and the most important results were in terms of weight/age, height/age, and weight/height values for each child (as these have been calculated for each age and according to World Health Organization reference values).

Another important limitation was the fact that there was no access to other variables that can directly influence the growth/development process (such as diet, exercise, parasitosis, pre-natal monitoring, etc.). These information could not be obtained as this was a study based on secondary data. On the other hand, our results can be considered as a baseline, in order to allow new studies to measure the influential variables in greater details. Moreover, the selection bias of the study population is implicit, since only a small population group was analyzed; however, as mentioned in the methodology section, the studied group may be similar to others at the national level, since the Peruvian government provides the social/assistance program to low-income areas across the country.

The findings obtained in this study lead us to conclude that in young children, hemoglobin levels, weight, and height are associated with the MMN intake. Nevertheless, we did not find a statistically significant association between the nutritional status and anemia. 


\section{REFERENCES}

1. Micronutrient Initiative. Investing in the future: a united call to action on vitamin and mineral deficiencies-Global report 2009 [online]. Ontario: Micronutrient Initiative, 2009. Available at: https://www.who.int/vmnis/publications/investing_in_the_future.pdf (Accessed 10 August, 2019)

2. Ministry of Health of Peru. Directiva sanitaria $n^{\circ} 056$-MINSA/DGSP v.01. Directiva sanitaria que establece la suplementación con multimicronutrientes y hierro para la prevención de anemia en niñas y niños menores de 36 meses [online]. Lima: Ministry of Health of Peru, 2014. Available at: http://bvs.minsa.gob.pe/local/MINSA/3933.pdf (Accessed 10 August, 2019)

3. Swaminathan S, Edward BS, Kurpad AV. Micronutrient deficiency and cognitive and physical performance in Indian children. Eur J Clin Nutr. 2013;67(5):467-74. https://doi.org/10.1038/ejcn.2013.14 PMid:23403875

4. Papale JF, Nieves García M, Torres M, et al. Anemia, deficiencias de hierro y de vitamina A y helmintiasis en una población rural del estado Lara. An Venez Nutr. 2008;21(2):70-6.

5. Strand TA, Taneja S, Kumar T, et al. Vitamin B-12, folic acid, and growth in 6- to 30-month-old children: a randomized controlled trial. Pediatrics. 2015;135(4):e918-26. https://doi.org/10.1542/peds.2014-1848 PMid:25802345

6. Wieringa FT, Dijkhuizen MA, Berger J. Consequences of micronutrient deficiency and interventions to improve micronutrient status. In: Watson RR, Grimble G, Preedy V, Zibadi S, editors. Nutrition in infancy. Totowa, NJ: Humana Press, 2013:333-42. https://doi.org/10.1007/978-1-62703-224-7_23

7. Galarza Pazmiño MA. Suplementación oral con micronutrientes para la prevención de anemia en niños menores de 7 años de la escuela «Nuestra Señora de la Elevación» de la comunidad de Misquilli de la parroquia Santa Rosa del periodo lectivo 2012 - 2013. [research work] [online]. Ambato: Universidad Técnica de Ambato, Facultad Ciencias de la Salud, 2013. Available at: http://repositorio.uta.edu.ec/bitstream/123456789/5867/1/MAR\%C3\% 8DA\%20DE\%20LOS\%20ANGLES\%20GALARZA.pdf (Accessed 10 August, 2019)

8. Ministry of Health of Peru. Indicadores del programa articulado nutricional según monitoreo nacional de indicadores nutricionales 2008 - 2010. Lima: Instituto Nacional de Salud; 2010.

9. Vargas-Vásquez A, Bado R, Alcázar L, Aquino O, Rodríguez A, Novalbos JP. Efecto de un suplemento nutricional a base de lípidos en los niveles de hemoglobina e indicadores antropométricos en niños de cinco distritos de Huánuco, Perú. Rev Peru Med Exp Salud Publica. 2015;32(2):237-44. https://doi.org/10.17843/ rpmesp.2015.322.1613 PMid:26338380

10. National Institute of Statistics and Informatics. Encuesta demográfica y de salud familiar-ENDES 2014 [online]. Lima: National Institute of Statistics and Informatics, 2015 Available at: https://www.inei.gob.pe/media/ MenuRecursivo/publicaciones_digitales/Est/Lib1211/pdf/Libro.pdf (Accessed 10 August, 2019)

11. Ministry of Health of Peru. Plan nacional para la reducción y el control de la anemia infantil y la desnutrición crónica infantil en el Perú: 2017-2021 [online]. Lima: Ministry of Health of Peru, 2017. Available at: http://bvs.minsa.gob.pe/local/MINSA/4189.pdf (Accessed 10 August, 2019)

12. Aparco JP, Bullón L, Cusirramos S. Impacto de micronutrientes en polvo sobre la anemia en niños de 10 a 35 meses de edad en Apurímac, Perú. Rev Peru Med Exp Salud Publica. 2019;36(1):17-25. https://doi.org/10.17843/rpmesp.2019.361.4042 PMid:31116334

13. Lazarte $S$, Issé B. Prevalencia y etiología de anemia en el embarazo. Estudio observacional descriptivo en el instituto de maternidad de Tucumán. Rev Argent Salud Pública. 2011;2(8):28-35.

14. Bruno-Huamán A, Valdivia-Lívano S, Mejia CR. Asociación de la densidad calórica de la leche materna según parámetros antropométricos de las madres y sus hijos. Rev Chil Obstet Ginecol. 2016;81(1):15-21. https://doi.org/10.4067/S0717-75262016000100003

15. Ministry of Health of Peru. Guía de práctica clínica para el diagnóstico y tratamiento de la anemia por deficiencia de hierro en niñas, niños y adolescentes en establecimientos de salud del primer nivel de atención [online]. Lima: Ministry of Health of Peru, 2015. Available at: http://bvs.minsa.gob.pe/local/MINSA/3932.pdf (Accessed 10 August, 2019)

16. Ministry of Health of Peru. Requerimientos de energía para la población peruana. [online]. Lima: Ministry of Health of Peru, 2012. Available at: https://web.ins.gob.pe/sites/default/files/Archivos/cenan/deprydan/ lamejorreceta/Requerimiento\%20de\%20energ\%C3\%ADa\%20para\%20la\%20poblaci\%C3\%B3n\%20peruana.pdf (Accessed 10 August, 2019) 
17. Chamorro Galindo JJ, Torres Arias KL. Efecto de la suplementación con multimicronutriente y estado nutricional en niños menores de tres años en comunidades de Huando y Anchonga - Huancavelica, 2010 [research work] [online]. Lima: Universidad Nacional Mayor de San Marcos, Facultad de Medicina Humana E.A.P. de Nutrición, 2012. Available at: http://cybertesis.unmsm.edu.pe/bitstream/handle/cybertesis/1162/Chamorro_gj.pdf? sequence $=1$ \&isAllowed $=y$ (Accessed 24 November, 2019)

18. Ministry of Health of Peru. Eficacia y efectividad de la suplementación de micronutrientes para la prevención de anemia, enfermedades y un adecuado crecimiento lineal y desarrollo cognitivo de la población infantil de 6 a 36 meses de edad [online]. Lima: Ministry of Health of Peru, 2012. Available at: http://plataformagets.sis.gob.pe/ bitstream/SIS/206/1/Nota\%20T\%C3\%A9cnica\%202012-7.\%20Eficacia\%20y\%20Efectividad\%20de\%20la\%20supl ementaci\%C3\%B3n\%20de\%20Micronutrientes\%20para\%20la\%20prevenci\%C3\%B3n\%20de\%20anemia.pdf (Accessed 10 August, 2019)

19. Huamán-Espino L, Aparco JP, Nuñez-Robles E, Gonzáles E, Pillaca J, Mayta-Tristán P. Consumo de suplementos con multimicronutrientes Chispitas ${ }^{\circledR}$ y anemia en niños de 6 a 35 meses: estudio transversal en el contexto de una intervención poblacional en Apurímac, Perú. Rev Peru Med Exp Salud Publica. 2012;29(3):314-23. https://doi.org/10.1590/S1726-46342012000300004 PMid:23085791

20. Selva Suárez LN, Ochoa Alonso AA. Acciones para la prevención y control de la anemia por deficiencia de hierro en niños hasta cinco años. Rev Cubana Salud Pública. 2011;37(3):200-6. https://doi.org/10.1590/S086434662011000300003

21. Del Castillo JMS. Nutrición básica humana . Valencia: Universitat de Valencia. Servei de Publicacions, 2006.

22. Munayco CV, Ulloa-Rea ME, Medina-Osis J, et al. Evaluación del impacto de los multimicronutrientes en polvo sobre la anemia infantil en tres regiones andinas del Perú. Rev Peru Med Exp Salud Publica. 2013;30(2):229-34. https://doi.org/10.17843/rpmesp.2013.302.196

23. Cabada MM, Goodrich MR, Graham B, et al. Prevalence of intestinal helminths, anemia, and malnutrition in Paucartambo, Peru. Rev Panam Salud Publica. 2015;37(2):69-75.

24. Anticona $C$, San Sebastian M. Anemia and malnutrition in indigenous children and adolescents of the Peruvian Amazon in a context of lead exposure: a cross-sectional study. Glob Health Action. 2014;7:22888. https://doi.org/10.3402/gha.v7.22888 PMid:24560254 PMCid:PMC3925814

25. Creed-Kanashiro $H$, Bartolini $R$, Abad $M$, Arevalo V. Promoting multi-micronutrient powders (MNP) in Peru: acceptance by caregivers and role of health personnel. Matern Child Nutr. 2016;12(1):152-63. https://doi.org/10.1111/mcn.12217 PMid:26522502 PMCid:PMC4738407

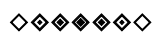

http://www.ejgm.co.uk 